IRA-International Journal of Management \& Social Sciences

ISSN 2455-2267; Vol.05, Issue 03 (2016)

Pg. no. 427-435

Institute of Research Advances

http://research-advances.org/index.php/RAJMSS

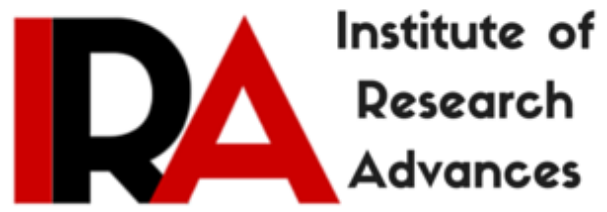

\title{
Work-life Balance a Strategic Human Resource Policies and Practices followed by Indian Organizations
}

\author{
Mrs. Pratibha Barik ${ }^{1}$, Dr. (Mrs.) B.B. Pandey ${ }^{2}$ \\ ${ }^{1}$ Research Scholar, Department of Management Studies, \\ Guru Ghasidas Vishwavidyalaya, Koni (Bilaspur), India. \\ ${ }^{2}$ Assistant Professor, Department of Management Studies, \\ Guru Ghasidas Vishwavidyalaya, Koni (Bilaspur), India.
}

Type of Review: Peer Reviewed.

DOI: http://dx.doi.org/10.21013/jmss.v5.n3.p5

\section{How to cite this paper:}

Barik, P., \& Pandey, B. (2016). Work-life Balance a Strategic Human Resource Policies and Practices followed by Indian Organizations. IRA-International Journal of Management \& Social Sciences (ISSN 2455-2267), 5(3), 427-435. doi:http://dx.doi.org/10.21013/jmss.v5.n3.p5

(C) Institute of Research Advances

\section{(cc) BY-No}

This work is licensed under a Creative Commons Attribution-Non Commercial 4.0 International License subject to proper citation to the publication source of the work.

Disclaimer: The scholarly papers as reviewed and published by the Institute of Research Advances (IRA) are the views and opinions of their respective authors and are not the views or opinions of the IRA. The IRA disclaims of any harm or loss caused due to the published content to any party. 


\section{ABSTRACT}

The study examines the innovative work-life balance policies and practices implemented by various Indian Companies. As with the increase of women workforce, dual earner families and increase in nuclear families have generated the need for the employees to balance their work and personal life. Further to provide better quality of life and to retain their talented employees companies are providing various Work Life programmes. The present paper has made an effort to reveal the present status of work-life balance programs and benefits offered by various well reputed Indian organizations and its prospect and future challenges. The study is based on the extent of literature review, empirical study and secondary data. It was found that many organizations have started taking initiative to overcome work-life conflicts. Practices like flexi-time, parental leaves, childcare assistance and counseling etc. have improved and these supports enhance the performance and behavior of an employee towards their organization. This holistic view of this paper will contribute to the work-life balance literature and discuss the implication for future research.

Key words: Work-life balance, Quality of life, Stress, family-friendly policies.

\section{Introduction:}

Work-life balance is defined as an employee's perception that multiple domains of personal time, family care, and work are maintained and integrated with a minimum of role conflict (Clark, 2000; Ungerson \& Yeandle, 2005). However the organizations are concern about their employees since industrialization as many companies were having many welfare policies like healthy working environment, safety and securities. Post war era saw the increase of government mandated provisions being offered to employees such as health and life insurance, social security like pension plans and disability protection in forms of worker's compensation for accidents, and diseases institutionalizing the notion that employers had at least some obligations to provide security to employees families (Glass \& Estes,1997).

With the changing demographic shift in the work place the Work-life balance has become the upcoming issue for the employees as well as for employers. As in a survey it showed 18 to $26 \%$ of rise in women's labour force participation in India. Thus the dual earners are increasing rapidly and creating a work-life conflict. This WLB policies are no more limited to female workforce, but male workers too feel the need of this. The study by Francene Sussner Rodgers (1992) with the sample consisting of employees of 20 Fortune 500 companies; 28 percent of the men and 53 percent of the women reported that work-family stress affected their ability to concentrate at work hence revealing that more than half the women and almost a third of the men reported that work/family stress affected their ability to concentrate on the job. Due to increasing demand for work-life balance it's tremendously pressurizing the organization to implement policies that helps an employee to balance the work and non-work performance. Environmental changes are evidenced in increasing number of firms in the services sector (NASSCOM Newsline, 2008a), which require employees to work longer, frequently interact with customers and work across varied time zones. This has eliminated the line between the work and family. As a result, initiatives such as flexible working hours, alternative work arrangements, leave policies and benefits in lieu of family care responsibilities and employee assistance programmes have become a significant part of most of the company benefit programmes and compensation packages. Such policies, practices and benefit programmes are generally referred as "family-friendly policies"(FFPs) or "work-life benefits and practices" (WLBPs) in literature (Kopelman et al., 2006; Kossek \& Ozeki, 1998).

This study is based on the empirical analysis of literature review, news articles and journals. The objectives of the research is to find out the innovate Work-Life Balance Policies followed by Indian organizations and what challenges are they facing. Further what are the prospects of Work-Life Balance Policies in Indian organization. 


\section{Work-Life Balance: A Strategic Approach}

Rajadhayaksha \& Smitha (2004) has stated that in a dual career family, work family role conflicts and organizational role stress were not significantly different among Indian husbands and wives. This demographic change has forced the organization to think beyond the Human Resource policies and further take initiative to adopt flexi working hours, leave policies for elderly and child care, onsite childcare and financial assistance. These practices in an organization results with less loss of knowledge workers to competitors (Dex and Scheibl, 1999)

The Four family-friendly HR practices are:

1- Flextime: A work arrangement wherein employees work a certain number of core hours, but has a freedom to start and end time.

2- Telework: A work to home provision wherein employees work at least some of their regularly scheduled hours at home and for pay. They use technology like laptop or mobile to stay communicated with their employers.

3- Childcare services: A variety of childcare support services, including information and referral services, assistance with external suppliers, or on-site centers.

4- Eldercare services: A variety of eldercare support services, including information and referral services, assistance with external suppliers, or on-site centres. For the purposes of this report, eldercare services were defined as "available" if employees indicated that their employer offered the service.

Work-life balance practices not only benefits a firm but the employees, the team and divisions where the WLB strategies are implemented. These benefits include increased morale, productivity and employee and customer engagement.

Along with various benefits the literature indicates that the implementing this strategy borne many costs, that's bear by the company. A company provides child care leave or a parental leave, so direct costs of policies which involve payments, such as childcare subsidies or paid parental leave (Dex and Scheibl, 1999; Dex and Scheibl, 2001). Then the costs of extra spaces associated with increased facilities such as breast feeding rooms or childcare facilities and equipment to facilitate working at home like, laptops, mobile (Evans, 2001). The costs incurred in investigating work-life balance policies and implemention new work-life balance policy systems like, costs associated with changing processes or culture and Fixed costs associated with the number of staff. Disruption costs for temporarily filling absent colleagues posts and its causes temporary reduction in productivity (Dex and Scheibl, 1999; Evans, 2001). Reduced morale of those employees not benefiting (Dex and Scheibl, 1999; Evans, 2001)

\section{Benefits of Work-Life Balance Practices}

Work-life balance, in its broadest sense, is defined as a satisfactory level of involvement or 'fit' between the multiple roles in a person's life (Hudson, 2005). WLBPs are those institutionalized structural and procedural arrangements, as well as formal and informal practices that make it easier for individuals to manage the often-conflicting worlds of work and family lives (Osterman, 1995).

Today with the demographic shift in the workforce women make up 40 percent of the global workforce, and they are becoming an increasingly important part of the world's formal workforce as they shift from agricultural work to industry and service sector jobs (International Labor Office, 2008). Family-friendly 
policies not only helps a female employee to manage with their multiple roles, but even male employees are able to cope up with the work and family responsibilities. Research findings show that WLBPs enhance their attitudes and behaviors such as organizational attachment (Grover and Crooker, 1995). However, in recent years, adoption of such programs and policies are being considered as a part of 'high commitment work systems' (Osterman, 1995) required for ensuring high levels of employee commitment and innovation.

Work-life practices helps to retain talented employees as they become more commitment towards their organization and hence it reduces attrition rate and absenteeism. It's a cost benefit to an organization as availability of WLBPs reduces employee absenteeism (Dex and Scheibl, 1999) and enhances organisation's productivity (Sands and Harper, 2007). However it improves recruitment and retention rates (Allen, 2001; Anderson, Coffey \& Byerly, 2002; Honeycut \& Rosen 1997; Konrad \& Mangel, 2000; Kossek \& Ozeki, 1998).

WLBPs has facilitated employees to overcome with their multiple work and non-work role conflicts. WLBPs have been found to increase employee control over time and place of work

(Thomas \& Ganster, 1995). Kofodimos (1993) suggests that imbalance-in particular work imbalancearouses high levels of stress, detracts from quality of life, and ultimately reduces individuals' effectiveness at work. This policies and practices are boosting the employees to manage their work and life, which reduces their stress and career success. A number of studies have found that employees who benefit from childcare centres, referral services and other family-supportive practices report higher levels of commitment to the organization (Goldberg, Greenberger, Koch-Jones, O'Neil, \& Hamill, 1989; Grover \& Crooker, 1995; Orthner \& Pittman, 1986; Youngblood \& Chambers-Cook, 1984). It's a strategic decision taken by HR department. As a company is not only benefited with WLBPs but employees are too enjoying it.

\section{Work-Life Balance Policies and Practices implemented by Indian Organizations}

With the increase in women workforce in India various policies like maternity benefit Act 1961, which provides 3 months, paid leave to all female employees. The Maternity leave has been

increased from the period of 135 days to 180 days by the Sixth Pay Commission. Soon with the Rajya Sabha passing The Maternity Benefit (Amendment) Bill, 2016, six months of maternity leave will soon be a reality for women working in the organised sector also. In 1999 the center through a notification under the central Civil Services (Leave) rule 551(A), made provision for paternity leave for a male central employees with less than two surviving child for a period of 15 days.

Many organizations have started implementing flexi time and telecommunicating through which its easier for an employee to work as per their convenience. It helps the companies in long run to retain their high potential workforce.

A 29-year old Nidhi Sharma, senior technical architect at HCL Technologies, who availed of the telecommuting policy for five months after the birth of her twin daughters. She says that "This was the only option that allowed me to take care of my kids" $"$.

Citi India recently introduced a policy to allow employees to work from home for two days a month if their role permits it. Employees can also opt for flexible work options such as flexi-time and remote

\footnotetext{
${ }^{1}$ In an article "Companies like Mindtree, Marico, Pepsico eager to help employees strike a better work-life balance" By Shreya Biswas \& Rica Bhattacharyya, ET Bureau | Mar 25, 2014, 06.44 AM IST
} 
working, depending on their role. The company recently introduced a Concierge Service within the office premises, helping free up valuable time for employees. These types of initiatives has resulted in happier and more committed employees and corroborated by a steady increase in employee satisfaction.

Further many companies are conscious for their employee's health wellness. PepsiCo India has introduced the concept of free and healthy breakfast that consists of fresh seasonal fruits, oats, upma, poha etc, Due to which the young unmarried employees staying alone and newly married couples are relieved from the morning breakfast tension. The company has tied up with day care facilities such as Ida and Intellitots and others, across the country (Gurgaon, Mumbai, Hyderabad, Lucknow, Chandigarh) where employees get heavy discounts under the corporate tie-ups to the tune of Rs 40,000-50,000, along with many other benefits. So the employees with small kids are stress free for their kids.

Dabur India is placing a lot of emphasis on health and fitness policies. A healthy employee is a productive employee. Coca Cola encourages its employees to be fit and fine. They encourage them to enroll in healthy living programmes like tennis, gym memberships, yoga, aerobics programmes and funds 50 per cent of the expenses incurred on memberships and equipments. Manhindra and Mahindra have tie ups with diagnostic center and Stepathlon Lifestyle where employee are allow to go for medical check-ups. Raychem RPG are upgrading their employee engagement measures by coming up with newer policies that provides 101 services, from parent care, services such as maintenance services of electronic goods, getting the laundry done to pet care. So that people can enjoy their time after work and on weekends.

At Marico, employees are free to decide their working hours in discussion with their senior officer. Company provide a unique contingency leave policy which can be availed by an employee at the time of illness or for any personal reason on oral approval of their supervisor and no leave record is maintained.

With all this ITES and BPO are one of the fast growing sectors in India and here the employees have to work $24 \times 7$. Managing a healthy balance of between work and life of their employees is the biggest challenge for the organizations. A leading IT company Infosys Technologies, has a wellness initiative called Health Assessment Lifestyle Enrichment (HALE) and Wipro too offers wellness initiative to help their employees to get distress.

In 2002 Johnson and Johnson India established Women's Leadership Initiative (WLI) and it was aimed to attract women leaders in the company. However $\mathbf{J} \& \mathrm{~J}$ focused on creating awareness on health issues like diabetes and AIDS, provided support to orphans, street children and tribal girls and gynecological and maternity care to women in need.

Work place flexibility and work to home are the measures taken by IBM India to motivate their employee for efficient performance and to initiate the joining of female workforce. At IBM, the percentage of employees working from home is $40 \%$ while at HP it is $25 \%{ }^{2}$.Procter \& Gamble India has been offering work from home for its employees, and reduced work schedules, both of which have been a great enabler in maximizing productivity and helping manage work-life balance.

The above analysis shows that companies are taking initiative to provide a family-friendly environment to their employees. A recent study by Kelly services (2009) revealed that personal communication technologies such as smart phones and laptops have improved work life balance and $92 \%$ of respondents in India agreed it.

\footnotetext{
2 In Times of India an article "Work from home new mantra for IBM employees" by SHRUTI SABHARWAL, DEVINA SENGUPTA \& INDU NANDAKUMAR | ET Bureau | Jun 24, 2011, 06.35 PM IST
} 


\section{Work-Life Balance Challenges and Prospects for Indian Organizations}

This research paper analyzed on literature review, news articles and secondary data reveals that Indian organizations are putting their best effort to provide a work-life balance programs. But still many organizations treat it as a burden, but not as a strategic decision. In 2013, the attrition rate for employees in India was $26.9 \%$ i.e. almost one of every four employees wants to change his job especially in Information Technology, Insurance and Pharmaceutical sector (Biswas, 2013).

In this current scenario, where companies are going global, the biggest challenge for the Human Resource Managers is to reduce the cost. The policy makers percept that introduction of Work-life policy will increase their budget thus will be quite difficult for them to survive in this competitive global market. In this new era where big changes are taking place in the careers of male as well as female employees. The employees are more and more career oriented, which some where conflict with their family life. So the organization can't only think for the welfare of their employees but they have to consider the kids (who are the unseen stakeholders at work) and the parents their employees. In a research by Stewart D. Friedman and Jeffrey H. Greenhaus ( ) revealed that parents' work experiences and career values influence children's health and welfare in significant ways. For instance, kids whose parents are more focused on career than on family have more behavior problems and do worse in school, because there is greater interference on these families from work.

In India where the demographic changes are taking place and the women workforce are entering into IT and ITES sector. The statutory policies such as maternity leave and benefits are common, while practices such as flexi-time, work from home and part-time work are still sporadic, since these practices are discretionary in nature (Baral). Other policies and practices like telecommunity, paternity leave, child care leave, health assistance programs, child care centers, parental care leave, stress release programs and trainings are yet to be taken as strategic decision by the organizations.

Today this Work-life balance is a challenging issue as Indian organizations have the advantage of young and energetic workforce. But to efficiently utilize these resources the Human Resource department has to explore some innovative policies and practices. The McCrindle Research study of 3000 Australians shows that work-life balance is the number one factor of job attraction \& retention (even above salary). The Workplace Employee Relations Survey 1998 suggests that the workplaces that are doing best on a number of dimensions were those with 'high commitment management practices' well embedded in the labour process, and where a large proportion of employees feel committed to the organisation. Hence it reduces abseentism, increase productivity and job satisfaction.

Many researchers have proof that work and family are no longer separate, but simultaneously influence each other. There is evidence that work and family are no longer two separate role domains rather are interdependent and have positive influence on each other (Greenhaus and Powell, 2006). In a study by Baral (2009) explored that in Indian organisations families significantly contributes to work in terms of enhancing performance and positive emotions at the workplace.

These policies and practices enhance the performance of an employee and motivate them to be more committed towards their job. All together family-friendly policies are advantageous for employees to keep them mentally distress, however it results in job satisfaction. It's the time to recognize the value and contribution of WLBPs on employee's lifestyle and organization performance.

\section{Conclusions and Recommendations}

Indian organizations are being recognized globally. With the changing demographic workforce it's no more a women oriented policies. Apart from this the adaptation of technology and female workforce the 
strategic implementation of WLBPs is very challenging for the Indian organizations. As the organization have to look for its successful implementation and even have to manage its budget. Although many top notch Companies like IBM, Tata groups, Johnson \& Johnson, Wipro, Pepsico and many have taken initiative to implement the WLBPs.

This revolutionary change will assist them to retain and explore the capabilities of their talented employees. The organizations are gradually analyzing and changing the policies as per their requirement and situation. Organizations have realized the power of Work-Life Balance mantra and are putting their best efforts to implement it successfully. Family-friendly policies adopted by the organizations can help the employees to decrease the work-family interface and yield benefits for themselves, their families and their employers.

\section{Work-Life Balance Outcomes}

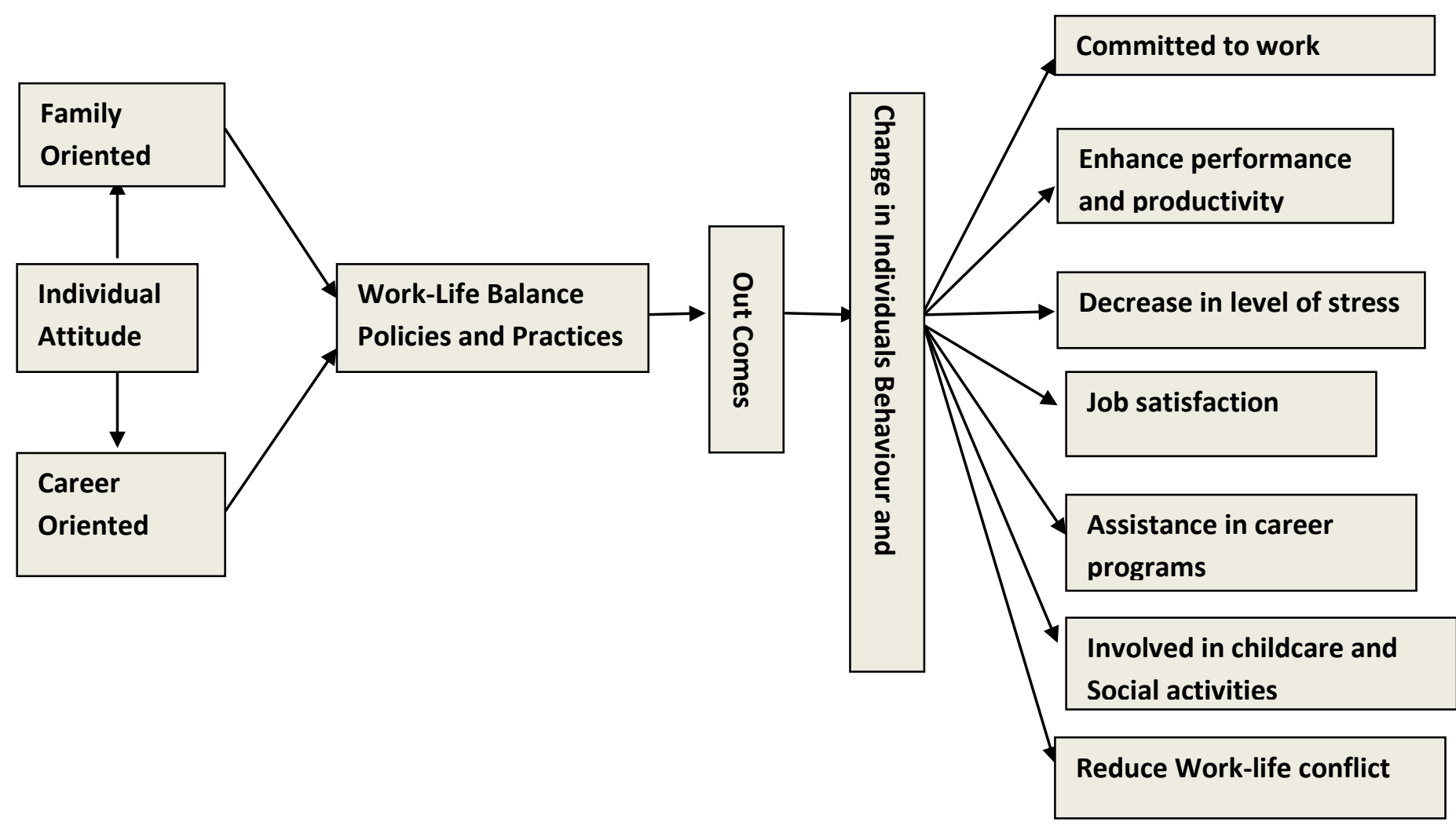


It has been concluded that employees are of two types: Family oriented and Career oriented. Careerfocused people are more involved in work and less psychologically involved in their families, whereas family-focused people adjust their work schedules to accommodate family or personal needs. To handle these employees with two different perspective organizations need to execute innovative and supportive work-life balance policies. The above figure shows that how an individual with the supportive WLBPs can be motivated to work efficiently in an organization and it brings changes in their attitude and behaviour. Indian companies have to work a lot for the successful implementation of these statutory benefits for the wellness of their workforce. Once they feel that its no more a burden but a strategic decision, they will take initiative to execute these work-life balance policies.

\section{References:}

- $\quad$ A.Meenakshi, .Metilda Bhuvaneshwari, Work Organization and Work -Life Balance in the BPO Sector **International Journal of Scientific and Research Publications, Volume 3, Issue 6, June 2013, pp-1-4.

- $\quad$ Biswas, S. (2013). Attrition in India to top world charts in 2013; one in four employees to change jobs, Article Economic Times, Accessed from ttp://articles.economictimes.indiatimes.com/201306-07/news/39815456_1_three-employees-indian-employees-attrition on 15th March 2015.

- Clark SC (2000).Work/Family Border Theory: A NewTheory of Work/Family Balance. Human Relations 53(6): 747-770.

- $\quad$ Dex and Scheibl, 1999, Flexible and family friendly working arrangements in UK based SMEs: Business cases, British Journal of Industrial Relations, Sept 2001, 0007-1080, pp-411-43.

- Evans, J.M.(2001) "Firms' Contribution to the Reconciliation between Work and Family Life", OECD Labour Market and Social Policy Occasional Papers, No. 48, OECD Publishing. http://dx.doi.org/10.1787/344836028454.

- $\quad$ Francene Sussner Rodgers, "When the Business Case Is Common Sense: Coming to Terms with America's Family Challenge," ACA Journal, (Autumn 1992).

- $\quad$ Friedman, S D and Greenhaus, J H (2000). "Work and family_Allies or enemies? What happens when business professionals confront life choices", New York: Oxford University Press.

- $\quad$ G.Delina \& R. Prabhakara Raya, A study on Work-Life Balance I, Working Women, International Journal of Commerce, Business and Management, Vol. 2, No.5, October 2013, pp-274-282

- Glass, J. L., \& Estes, S. B. (1997). The family responsive workplace. Annual Review of Sociology, 23(1), 289-313.

- Grover, S.L., and Crooker, K.J. 1995. Who appreciates family-responsive human resource policies, The impact of family-friendly policies on the organisational attachment of parents and non-parents, Personnel Psychology, 48, pp.271-288.

- $\quad$ Hill, E.J., Grzywacz, J.G., Allen, S., Blanchard, V.L., Matz-Costa, C., Shulkin, S., \& PittCatsouphes, M. (2008). Defining and conceptualising workplace flexibility. Community, Work, and Family, 11, 149-163.

- $\quad$ http://economictimes.indiatimes.com/news/company/corporate-trends/companies-like-mindtreemarico-pepsico-eager-to-help-employees-strike-a-better-work-life-

balance/articleshow/32621823.cms

- $\quad$ http://shodhganga.inflibnet.ac.in/bitstream/10603/30836/9/09_chapter4.pdf

- $\quad$ http://thewire.in/58661/rajya-sabha-passes-maternity-leave-bill-extends-leave-to-six-months/

- $\quad$ http://timesofindia.indiatimes.com/tech/jobs/Work-from-home-new-mantra-for-IBM-

employees/articleshow/8977592.cms

- $\quad$ http://www.bc.edu/cwf

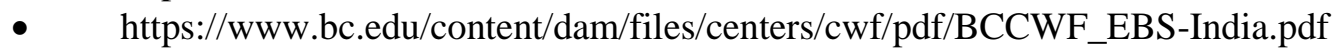

- Jagdeep Singh, Individual and Organizational Strategies to Balance Work-life with Indian Way, Global Journal of Management and Business Studies. Volume 3, Number 3 (2013), pp. 203-210. 
- $\quad$ Kopelman et al., 2006; Kossek \& Ozeki, 1998. An Empirical Study on Exploration of Work Life Balance in Innovation in management Challenges and Opportunities in the Next Decade, M.S.Rangaraju, and S.Hanuman Kennedy. (editors), pp. 211.

- $\quad$ Mohanty, A. and Jena, L.K. (2016) Work-Life Balance Challenges for Indian Employees: SocioCultural Implications and Strategies. Journal of Human Resource and Sustainability Studies, 4, 1521. http://dx.doi.org/10.4236/jhrss.2016.41002.

- Nick, B., Tobias K. and John, V.R., (2006), Management Practices and Productivity, http://cep.lse.ac.uk/management/worklifebalance_research.pdf.

- $\quad$ Orthner, D. K., \& Pittman, J. F. (1986). Family contributions to work commitment. Journal of Marriage and the Family, 48(3), 573-581. http://indianexpress.com/article/india/india-newsindia/govt-to-increase-maternity-leave-in-pvt-sector-from-12-to-26-weeks/.

- Osterman, P. 1995. Work/family programmes and the employment relationship, Administrative Science Quarterly, 40, 681-700.

- $\quad$ R. Baral \& S. Bhargava; "HR interventions for work-life balance: evidences from organisations in India”. International Journal of Business, Management and Social Sciences, Vol. 2, No. 1, 2011, pp. 33- 42.

- $\quad$ Rupashree Baral, S Bhargava, Work-life Balance Practices in Indian Organisations: Challenges and Prospects, Work-life Balance, NHRD Network Journal, July2009 Volume2 Issue3 , pp-53-58.

- $\quad$ Sakthivel, R., Kamalanabhanb \& Selvarania(2011), Work/Life Balance Reflections on Employee Satisfaction, Serbian Journal of Management, Vol.6 Iss (1), pp-85 - 96, www.sjm06.com

- $\quad$ Sands, J. and Harper, T.L. 2007. Family-Friendly Benefits and Organisational Performance, Business Renaissance Quarterly, 2, 107-126.

- Shravanthi, A., Deshmukh, S., Deepa,N., (2013) Work Life Balance of Women in India, International Journal of Research in Management Sciences, Vol. 1, Issue 1, pp-47-56.

- $\quad$ Susi.S1, Jawaharrani.K, Work-Life Balance: The key driver of employee engagement, ASIAN JOURNAL OF MANAGEMENT RESEARCH , Volume 2 Issue 1, 2011, PP-474-483.

- Taneja, A. (2015), Work Life Balance Practices \& Employee's Turnover Intention in an Organization, Research Journal of Social Science and Management, Volume: 05, Number: 7, pp1551-158.

- Ujvala Rajadhyaksha, Swati Smita, Tracing a Timeline for Work and Family Research in IndiaEconomic and Political Weekly April 24, 2004, pp-1674-1680.

- $\quad$ Umene-Nakano W, Kato TA, Kikuchi S, Tateno M, Fujisawa D, et al. (2013) Nationwide Survey of Work Environment, Work-Life Balance and Burnout among Psychiatrists in Japan. PLoS ONE 8(2): e55189. doi:10.1371/journal.pone.0055189.

- Youngblood, S., \& Chambers-Cook, K. (1984). Child care assistance can improve employee attitudes and behavior. Personnel Administrator, Vol.29, pp-45-47. 